ROADS TO THE TEMPLE 
This page intentionally left blank 


\section{LEON ARON}
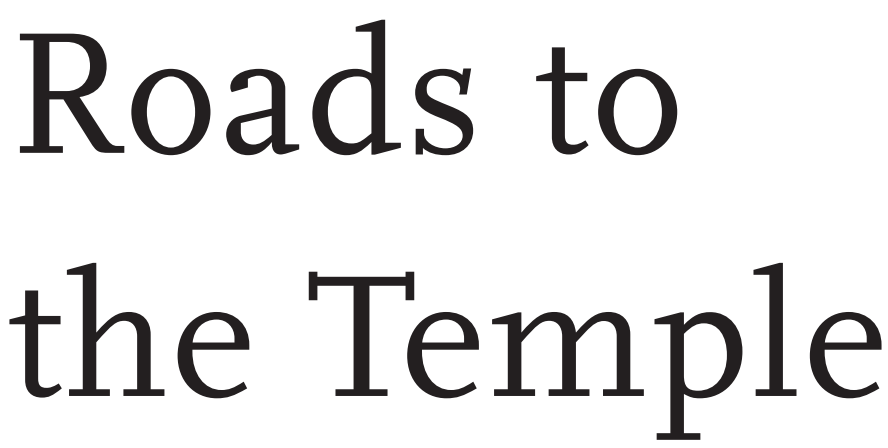

TRUTH, MEMORY, IDEAS, AND IDEALS IN THE MAKING OF THE RUSSIAN REVOLUTION, 1987-1991

Yale University press

NEW HAVEN AND LONDON 
Published with assistance from the foundation established in memory of Philip Hamilton McMillan of the Class of 1894, Yale College.

Copyright (C) 2012 by Leon Aron.

All rights reserved.

This book may not be reproduced, in whole or in part, including illustrations, in any form (beyond that copying permitted by Sections 107 and 108 of the U.S. Copyright Law and except by reviewers for the public press), without written permission from the publishers.

Yale University Press books may be purchased in quantity for educational, business, or promotional use. For information, please e-mail sales.press@yale.edu (U.S. office) or sales@yaleup.co.uk (U.K. office).

Set in Scala type by Westchester Book Group.

Printed in the United States of America.

Library of Congress Cataloging-in-Publication Data

Aron, Leon Rabinovich.

Roads to the temple : truth, memory, ideas, and ideals in the making of the Russian revolution, 1987-1991 / Leon Aron.

pages ; $\mathrm{cm}$

Includes bibliographical references and index.

ISBN 978-0-300-11844-5 (cloth : alkaline paper) 1. Soviet Union-History-1985-1991.

2. Glasnost. 3. Social action-Soviet Union. 4. Social change-Soviet Union.

5. Values-Soviet Union. 6. Soviet Union-Moral conditions. 7. Collective memorySoviet Union. 8. Soviet Union-Intellectual life-1970-1991. I. Title.

DK286.A76 2012

$947.0854-\mathrm{dc} 23$

2011047918

A catalogue record for this book is available from the British Library.

This paper meets the requirements of ANSI/NISO Z39.48-1992 (Permanence of Paper).

$\begin{array}{llllllllll}10 & 9 & 8 & 7 & 6 & 5 & 4 & 3 & 2 & 1\end{array}$ 
For Carol, Andrea, Dani, and Alexandra

For Mother and Father 
The invocation to historians to suppress even that minimal degree of moral or psychological insight and evaluation which is necessarily involved in viewing human beings as creatures with purposes and motives ... seems to me to spring from a confusion of the aims and methods of the humane studies with those of natural science. . . It becomes the business of historians to investigate who wanted what, and when, and where, in what way; how many men avoided or pursued this or that goal and with what intensity; and, further, to ask under what circumstances such wants or fears have proved effective, and to what extent, and with what consequences.

-Isaiah Berlin, Four Essays on Liberty

I shall begin by depicting them as they were in the heyday of the Revolution; when love of equality and the urge to freedom went hand in hand; when they wished to set up not merely a true democratic government but free institutions, not only to do away with privileges but also to make good and stabilize the rights of man, the individual. ... That [was an] age of fervid enthusiasm, of proud and generous aspirations, whose memory, despite its extravagances, men will forever cherish: a phase of history that for many years to come will trouble the sleep of all who seek to demoralize the nation and reduce it to a servile state.

-Alexis de Tocqueville, The Old Regime and the French Revolution 